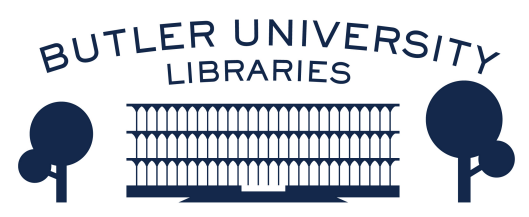

Journal of Hindu-Christian Studies

Volume 5

Article 6

January 1992

\title{
Mahatma Gandhi: A Living Embodiment of Hindu-Christian Dialogue
}

Devadatta Dabhokar

Follow this and additional works at: https://digitalcommons.butler.edu/jhcs

Part of the Religion Commons

\section{Recommended Citation}

Dabhokar, Devadatta (1992) "Mahatma Gandhi: A Living Embodiment of Hindu-Christian Dialogue," Journal of Hindu-Christian Studies: Vol. 5, Article 6.

Available at: https://doi.org/10.7825/2164-6279.1059

The Journal of Hindu-Christian Studies is a publication of the Society for Hindu-Christian Studies. The digital version is made available by Digital Commons @ Butler University. For questions about the Journal or the Society, please contact cbauman@butler.edu. For more information about Digital Commons @ Butler University, please contact digitalscholarship@butler.edu. 


\title{
Mahatma Gandhi: A Living Embodiment of Hindu-Christian Dialogue
}

\author{
Devadatta Dabholkar \\ Godoli, Satara City, Maharashtra
}

1 CAN ONLY outline the main approach to this theme in the brief space available. I am aware that it would require a much more detailed and documented statement. I am also doing this exercise mostly under quotation marks to ensure authenticity. Even quotations, however, can be slippery and deceptive if torn out of their context and chronology. I can only hope that this summary statement will bear out closer scrutiny.

A statement from the first volume (Autumn 1988) of Hindu-Christian Studies Bulletin could be a convenient starting point. In the Hindu-Christian Dialogue: A Review carried by this issue, the Review refers to the development of "Inner Dialogue." It also elaborates the nature of the Inner dialogue. It states: "Inner dialogue includes both the impulse which leads one to desire outer or interreligious dialogue and the effects of outer dialogue on one's own faith.... The aim is an inner reflection upon the teachings and practices of the different religion which leads to new insights and integrations in the experience of one's own religion." (p. 4)

Mahatma Gandhi lived this Inner Dialogue. ${ }^{2}$ Moreover, he did so-or in any case did his best to do so-in relation to all religions. His inner dialogue with Christianity, however, appeared to be more intimate as he was more in tune with the life and teachings of Jesus in his own thoughts and actions.

Thus he said in 'The Modern Review' a monthly journal published from Calcutta:

I believe that it is impossible to estimate the merits of the various religions of the world, and, moreover, I believe that is unnecessary and harmful even to attempt it. But each one of them, in my judgment, embodies a common motivating force; the desire to uplift man's life and give it purpose. And because the life of Jesus has the significance and the transcendency to which I have alluded, I believe that $\mathrm{He}$ belongs not only to Christianity, but to the entire world, to all races and people-it matters little under what flag, name or doctrine they may work, profess a faith, or worship-God inherited from their ancestors. 3

In his speech delivered at the First Annual Meeting of the Federation of International Fellowships held at his Satyagraha Ashram at Sabarmati, from January 13th to 15th in 1928, he was even more explicit. He said:

After long study and experience, I have come to the conclusion that (i) all religions are true; (ii) all religions have some error in them; (iii) all religions are almost as dear to me as my own Hinduism, in as much as all human beings should be as dear to one as one's close relatives. My own veneration for other faiths is the same as that for my own faith; therefore no thought of conversion is possible. The aim of Fellowship should be to help a Hindu to become a better Hindu, a Mussalman to become a better Mussalman, and a Christian a better Christian. The attitude of patronizing toleration is false to the spirit of International Fellowship. If I have a suspicion in my mind that my religion is more or less true, and that others' are more or less false, instead of being more or less true, then, though I may have some sort of fellowship with them, it is of an entirely different kind from the one we need in the International Fellowship. Our prayer for others must be NOT "God, give him the light that Thou hast given me" BUT "Give him all the light and truth he needs for his highest development." Prayer merely that your friends may become better men, whatever their form of religion. 4 
Mahatma Gandhi held this position to the very last moment of his life-in fact, he sacrificed his life for holding and preaching it.

Even many devout Christians have compared Mahatma Gandhi with Jesus Christ. Mahatma Gandhi, in all humility, would not have liked this high comparison. He said about Jesus: "A man who was completely innocent offered himself as a sacrifice for the good of others, including his enemies and became the ransom of the world. It was a perfect act." $\mathrm{Ma}$ hatma Gandhi considered himself to be far from perfect and did not like the epithet 'Mahatma' (meaning 'a great soul') being attached to his name.

The comparison however, persists in the mind of the whole world. When after Mahatma Gandhi's assassination Albert Einstein said: "Generations to come may scarce believe that such a man in flesh and blood ever walked on this earth," he was expressing not only his own personal view but the feeling of the entire world.

The testimony of Dr. Martin Luther King Jr. is even more significant. Mahatma Gandhi and Dr. King never met. In 1948, the year Gandhi was assassinated, Dr. King was named assistant pastor of his father's Baptist church in Atlanta, Georgia. He came to know about Mahatma Gandhi later. Dr. King writes:

Prior to reading Gandhi, I had about concluded that the ethics of Jesus were only effective in individual relationship.... Gandhi was probably the first person in history to lift the love ethic of Jesus above mere interaction between individuals to a powerful and effective social force in a large scale. It was in this Gandhian emphasis on love and non-violence that I discovered the method for social reform that I had been seeking for so many months. ${ }^{6}$

\section{Dr. King says further on:}

It must be emphasized that non-violent resistance is not a method for cowards; it does resist.... Gandhi often said that if cowardice is the only alternative to violence, it is better to fight.... Non-violent resistance is ultimately the way of the strong man. It is not a method of stagnant passivity.

We could call for more testimony from Dr. King; but it is not necessary.

We need only note here that Mahatma Gandhi himself held a slightly different view about the passive resistance of Jesus. It is recorded in the Harijan dated 07-12-1947 (p. 453). He says:

Europe mistook the bold and brave resistance, full of wisdom, by Jesus of Nazareth for passive resistance, as if it was of the weak. As I read the New Testament for the first time, I detected no passivity, no weakness about Jesus as depicted in the four gospels, and the meaning became clearer to me when I read Tolstoy's Harmony of the Gospels and his other kindred writings. Has not the West paid heavily in regarding Jesus as a Passive Resister? Christendom has been responsible for the wars which put to shame even those described in the Old Testament and other records, historical or semi-historical. I know that I speak under correction, for I can but claim very superficial knowledge of history-modern or ancient. ${ }^{8}$

The true test whether one as assimilated and fully internalized 'The Inner Dialogue', however, comes when a near relative is getting converted to another religion or someone in your family is marrying a person belonging to another faith. Mahatma Gandhi fulfilled these tests in his personal life and also in the advice that he gave to others. One of his sons embraced Islam and he was never cross with his son on that score. Similarly, he wrote the following letter to a Hindu brahmin whose father had got converted to Christianity. ${ }^{9}$

Dear friend,

I congratulate you all on your not in any way interfering with your father in doing what he thought was right. If you are sure that Hinduism gives you the peace you need it is your duty to retain it in spite of your father's change of faith.

Yours sincerely,

\section{M.K. Gandhi.}

How many of us can face such a litmus test of 'The Inner Dialogue'? 


\section{Footnotes}

1 In relation to quotations from his own writings Mahatma Gandhi said:

I would like to say to the diligent reader of my writings and to others who are interested in them that I am not at all concerned with appearing to be consistent. In my search after Truth I have discarded many ideas and learnt many new things. Old as I am in age, I have no feeling that I have ceased to grow inwardly or that my growth will stop at the dissolution of the flesh. What I am concerned with is my readiness to obey the call of Truth, my God, from moment to moment, and, therefore, when anybody finds any inconsistency between any two writings of mine, if he has still faith in my sanity, he would do well to choose the later of the two on the same subject. Harijan, 29-4-1933, p.2.

2 "Hindu-Christian Dialogue: A Review" makes a brief reference to Gandhi. Hindu-Christian Studies Bulletin, Vol. 1, Autumn 1988, p. 3.

3 Quoted in: R.K. Prabhu and V.R. Rao, The Mind of Mahatma Gandhi, p. 99, 1967, Navjivan Trust Ahmedabad, Number of the Issue not given.

4 Report of the Meeting.

5 Harijan, April 13, 1940, p. 92. Quoted in M.K. Gandhi: The Way to Communal Harmony, p. 225, 1963, Navjivan Publishing House, Ahmedabad.

6 Norman Cousins, Profiles of Gandhi, p. 207, 1969, Indian Book Company, Delhi.

7 Ibid. p. 209.

8 From The Mind of Mahatma Gandhi, pp. 146-7.

9 This letter was written in May 1934. The recipient was Shri. G.N. Harshe. The original is with the recipient.

\title{
Response to Devadatta Dabhollkar
}

\author{
David C. Scott \\ United Theological College, Bangalore, India
}

I WANT TO begin my "response"-which is in actuality more of the nature of participating in a conversation - to Professor Dabholkar's observations by saying how much I appreciate his setting the tone of our interchange by stressing the centrality of the "inner dialogue" in Gandhiji's life. Certainly this is an essential element for an adequate understanding the incredible mahatma, or "great soul." Despite the obvious differences in faith nurtured by the Hindu and Christian religious traditions, Gandhiji, in his own peculiar manner, attempted to live out the Hindu and Christian modes of life. Gandhi, the Hindu, was suffused by what he himself spoke of as the "Christ-like spirit which uniquely expresses both the spirit and the will of God, and exists among us." Perhaps we can further our appreciation of this crucial constituent in Gandhiji's life by probing a bit more deeply while remaining sensitive to the dynamic of the "inner dialogue," so rightly stressed by Professor Dabholkar.

One of the major themes which is normally stressed as a fundamental basis for interreligious dialogue, is a shared common humanity. But it seems obvious that this common humanity remains an abstract idea and cannot carry concrete meaning unless some measure of it is expressed in some persons or groups of persons. Further, the degree of such common humanity can probably most adequately be gauged by the acceptability of such persons or groups of persons by all concerned. Judging by this criterion in the context of our current concern, one is hard pressed to think of others who represented the common humanity of both Hindus and Christians to a 